\title{
U.S. Indo-Pacific Strategy
}

Be Careful What You Wish For

\author{
Robert A. Manning
}

\begin{abstract}
The Indo-Pacific region is becoming the locus of growing U.S. and Chinese competition to shape the 21 st century regional and global system. While a trendy buzzword, the Indo-Pacific concept is not really new, but rather an extension of the longstanding U.S. Asia-Pacific strategy to reflect two new realities: India's becoming a more substantial economic and strategic actor in the Asia-Pacific; and the rapid ascension of China as an economic and military peer competitor of the U.S.

The new U.S. emphasis on enhanced involvement in the Indo-Pacific reflects a failure of previous U.S. policies towards China and a new, more aggressive response to what Trump administration views as a strategic competitor. But the U.S.-China relationship and the economic and security dynamics of the IndoPacific are riddled with complexities and contradictions that raise questions about
\end{abstract}

\section{Robert A. Manning}

Senior Fellow, Atlantic Council; Foresight, Strategy and Risks (FSR) Initiative.

ORCID: 0000-0001-6452-0142

Scopus 7201726066

6303 Avalon Drive, Bethesda, Md 20816

Ph: 240-274-6812

rmanning@acus.org

Atlantic Council

1030 15th Street, NW, 12th Floor

Washington, DC 20005 USA

Tel: 202.778.4952

info@AtlanticCouncil.org

This article is an expanded and revised version of the paper written for the Valdai International Discussion Club. The original copy is available at: http://valdaiclub.com/a/valdai-papers/valdaipaper-89-us-indo-pacific-strategy/?sphrase_id=501924 
both the Chinese and American policies. How this drama plays out will have no small impact on a global and regional system in transition looking out to 2025.

Keywords: the Indo-Pacific region, U.S. strategies, China, trade confrontation

\section{“Free and Open Indo-Pacific" (FOIP) has become a trendy buzzword, as evident at the recent APEC and East Asia Sum- 1 mits, dominating discussions about the future of Asia. But is} it actually a new concept, a new map of Asia-or more a repackaging of longstanding U.S. policies towards the Asia-Pacific in new and uncertain circumstances, a moment of historic transition both globally and in the region?

As the U.S. has begun to put flesh on the bones of its nascent FOIP policy, it appears an increasingly serious, if not problematic, effort to both rejuvenate and expand the Asia-Pacific policy it inheritedObama's so-called "rebalance" to Asia to compete with and counterbalance China in the region. While the animating ideas have been outlined, and undergirded by modest amounts of pledged funding, the exercise faces profound challenges, contradicted by the logic of Trump's "America First" philosophy and the overarching realities of U.S. global policies (For U.S. financial promises see: Pompeo, 2018a; Thrush, 2018).

The Indo-Pacific concept, on one level, is simply an extension of the Asia-Pacific notion to reflect the reality of India, which with its "Look East, Act East" policy has increasingly become an economic and strategic actor in a larger maritime theater in this century. Undoubtedly, the Indo-Pacific (or perhaps Indo-Asia-Pacific) is a legitimate geographic and strategic construct. In practical terms, it has meant a modestly enhanced military role to the "Pivot" or "rebalance" of the Obama administration stretching it from AsiaPacific to India, itself only a modest extension of the long-standing U.S. policy towards Asia-Pacific (first outlined by Secretary of State Hillary Clinton (2011); for an example of the longstanding U.S. policy see, for instance, the Department of Defense's East Asian Strategy 
Report, 1998). In bureaucratic terms, this corresponds to the area of responsibility of the U.S. Pacific Command, recently renamed the Indo-Pacific Command.

On the positive side, the U.S. Indo-Pacific strategy reflects continuity with longstanding U.S. goals-open markets, rule of law, peaceful settlement of disputes, freedom of navigation, and opposition to any hegemon or hegemonic coalition dominating Eurasia.

But it also reflects a significant shift in the U.S. policy towards China from one balancing the cooperative and competitive elements towards one viewing Beijing predominantly as a strategic competitorarticulated in the latest U.S. National Security Strategy-a shift that occurred gradually and then suddenly (NSS, 2017).

American concerns about China's re-emergence becoming less benign than anticipated by U.S. policy-makers and foreign policy specialists predated the arrival of Donald Trump to the White House. Since China began its "reform and opening" policies in 1979, two core assumptions underpinned a rough bipartisan consensus for U.S. policy: 1) as China integrated itself into the global economy and institutions and grew a large middle class, it would become an accepting stakeholder of the rules-based order with a large overlap of common U.S.-China interests enabling cooperation; 2) and that political reform, if not democracy, would follow.

U.S. perceptions that these assumptions were being proven wrong occurred incrementally over the past decade. A mea culpa by two former Obama administration officials summed it up: "Washington now faces its most dynamic and formidable competitor in modern history. Getting this challenge right will require doing away with the hopeful thinking that has long characterized the United States' approach to China" (Campbell and Ratner, 2018). The current U.S.China trade clash is a manifestation of this shift, an effort to push back against Chinese predatory mercantilism, the economic component of a larger effort to counter Chinese power. The magnitude of the shift in U.S. thinking about China was best captured in a remarkable recent speech in Singapore by former U.S. Secretary of the Treasury and a leading advocate of expanding economic cooperation with China, 
Henry Paulson. Paulson indicted China's current trade and investment practices and explained: "In large part because China has been slow to open its economy since it joined the WTO, the American business community has turned from advocate to skeptic and even opponent of past U.S. policies towards China. American business doesn't want a tariff war but it does want a more aggressive approach from our government. How can it be that those who know China best, work there, do business there, make money there, and have advocated for productive relations in the past, are among those now arguing for more confrontation?" (Paulson, 2018).

Thus, thereis a rough newU.S. consensus that China is predominately a strategic competitor. But the relationship remains more complex, as top U.S. officials concede. After a recent Economic and Security Dialogue with Chinese counterparts, Secretary of State Mike Pompeo said: "Even as our countries confront important differences in the bilateral relationship between the nations, our cooperation remains essential on many, many central issues" (Pompeo, 2018b). Defense Secretary Mattis was even more emphatic: "The United States seeks a constructive, reciprocal, and results-oriented U.S.-China relationship, one that benefits the Indo-Pacific and the world. We continue our commitment to explore new areas of cooperation on strategic issues of mutual concern like space, cyber, and nuclear capabilities, as well as reinforce the importance of military-to-military exchanges for our bilateral relationship" (Mattis, 2018a).

Regardless of how they try to explain it, an "Indo-Pacific" strategy is best understood as an effort to reinforce an updated rules-based order and counter-balance a re-emergent China, not only as a leading global power, but also as a major maritime actor.

\section{CHINA RENASCENT}

The U.S. shift should be viewed as a response to a growing multidimensional Chinese assertiveness over the past decade. It was after the 2008-2009 Western financial crisis that China abandoned Deng Xiaoping's strategic guidance: "Hide your strength, bide your time." There appeared a sense that China's historic moment had arrived: 
the U.S. financial system and "Washington Consensus" ideology had collapsed. This sense of triumphalism was captured in a rare published article by the head of China's Central Bank, Zhou Xiaochuan, calling for the RMB to replace the U.S. dollar as the world's main reserve currency (Barris, 2014). Beijing had a sense that the time was ripe to raise its global and regional profile.

In July 2009, then Chinese President Hu Jintao delivered a speech calling for China to increase its global power and influence (Masuda, 2016). Beijing began to pursue more pro-active political and military actions, most apparent in the South China Sea. China elevated its claims to disputed islets and reefs to a "core interest," a category previously reserved for Tibet and Taiwan. Beijing stepped up maritime activities in the East and South China Seas, later building military facilities on 3,200 reclaimed acres on disputed territory there that it controlled (Swaine, 2010). And recent reports, based on satellite images suggest China is still building (Blanchard and Gao, 2018). Overall, China claims about ninety percent of the South China Sea-the percentage eludes precision because Beijing has used an ambiguously defined "nine-dash line." Their claims have been discredited: The United Nations Convention on the Law of the Sea (UNCLOS) International Tribunal at The Hague rejected all Chinese claims and positions in July 2016 (although China refused to litigate a case brought by the Philippines) (Santos, 2016). The Beijing government rejects the court's finding - a move incompatible with China's accession to the UNCLOS in 1994 but consistent with the "indisputable" Chinese sovereignty claimed by Beijing.

Similarly, little opening appears to exist in the tangle of conflicting national positions about ultimate sovereignty in parts of the East China Sea. Beijing disputes Japan's claims to the Senkaku Islands, which are called Diaoyu in Chinese. Following the Second World War and into the 1970s, Beijing had occasionally raised pro forma objections to the transfer of the islands' administrative control to Tokyo, but indications of displeasure have risen in recent decades. For the past several years, China has dispatched coast guard vessels and military aircraft to the air and sea zones adjacent to the islands, which represents, in Japan's 
view, an attempt to disrupt Tokyo's ability to administer the territories. A measure of the pace of increased competition in the area can be found in the number of announced occasions $(1,168)$ in which Japan scrambled its fighter jets in 2016 (Jonson, 2017).

In 2017, tensions over Doklam extended this irredentism to the Himalayas. China and India have made no adjustment to some of their respective territorial claims. From New Delhi's perspective, the perception of Chinese intentions and use of language regarding Doklam seems to reflect a pattern employed in both the South China and East China Seas. In this view, China appears to be attempting to change the status quo either by force or by assertiveness backed by force, all aimed at creating new facts on the ground. In Bhutan, a road near a contested border becomes the instrument of assertion.

The language Beijing uses to speak about the Doklam dispute is employed to buttress China's claims in the South and East China Seas. At a June 28, 2017 press conference, for example, China's Foreign Ministry spokesperson Lu Kang explained that, "Doklam has been a part of China since ancient times. It does not belong to Bhutan, still less India... China's construction of roads in Doklam is an act of sovereignty on its own territory" (Goswami, 2018). This echoes China's claims in the South China Sea of "indisputable sovereignty... since ancient times," as noted in a background paper from Xinhua, the state news agency (2016).

The convergence of these views, coupled with an inclination to disregard or reinterpret some provisions in the UNCLOS Treaty (the right of "innocent passage" in [disputed] territorial waters), suggest an a la carte approach to the global rules-based order, and a pattern of Chinese irredentism. Xi Jinping's report to the 19th Party Congress repeatedly emphasized "the rejuvenation of the Chinese nation," stressing China's focus on "global combat capabilities" and vowed that in this new era, China will "move closer to the center of the world" stage (Xi, 2017).

China's creation of the Asian Infrastructure Investment Bank (AIIB) and its Belt and Road Initiative (BRI), a \$1.2 trillion vision to reconnect the Eurasian landmass and maritime silk road, stand as 
major signposts of China's desire to play a leading global role. Similarly, its remarkable rapid rise as a leading technology innovator, mobilizing its resources to create national champions through programs such as its "Made in China 2025" and declared goal leading the world in Artificial Intelligence by 2030 are the economic underpinnings of Chinese ambition (Wübbeke et al, 2017; also on Artificial Intelligence see: Lee, 2017). China is second only to the U.S. in R\&D, and its venture capital industry has begun to rival that of Silicon Valley (Economist, 2018).

\section{U.S. SEARCH FOR STRATEGY}

Even if China were not displaying signs of a competing vision of regional and world order, the U.S. has had great difficulty in adapting its policies to the dynamics of a multipolar world. But the remarkable pace and scope of China's economic and strategic ascendance has been something of a shock to the system. The U.S. record $\$ 375$ billion trade deficit with China, and its building of military bases in the South China Sea are emblematic of a jolt to U.S. sensibilities, with the evolving "free and open Indo-Pacific" response.

The Trump administration has borrowed the term from Japanese Prime Minister Shinzo Abe. Abe initially outlined it during his first term in office, in a 2007 speech to the Indian Parliament: "The Pacific and the Indian Oceans are now bringing about a dynamic coupling as seas of freedom and of prosperity. A 'broader Asia' that broke away geographical boundaries is now beginning to take on a distinct form. Our two countries have the ability-and the responsibility-to ensure that it broadens yet further and to nurture and enrich these seas to become seas of clearest transparence" (Abe, 2007).

During Abe's current tenure, he has refined the concept further and made Indo-Pacific connectivity a central theme guiding Japan's security and economic aid and investment policies. In a 2016 speech Abe defined it, explaining that "the goals of this strategy are to transform the Indo-Pacific region into a region without force and coercion, a region of freedom, a region ruled by law, a region focused on the market economy and a prosperous region" (Brown, 2018). Tokyo sees three pillars: values and principles-democracy, rule of 
law, free markets; freedom of navigation, improving physical and institutional connectivity; security and stability, enforcing maritime freedom (Asia Security Initiative, 2018).

The U.S. version of this Indo-Pacific strategy echoes that of Abe's, though it is still a work in progress, and to some degree bumps up against Trump's "America First" ideology. For Abe, free trade is central to Indo-Pacific connectivity. This is also a tenet of Australia's 2017 Foreign Policy White Paper, which also places emphasis on the IndoPacific (White Paper, 2017). But Trump has pursued protectionist policies and has an aversion to multilateral institutions that the U.S. has been instrumental in creating and sustaining-what he calls "globalism,"-though in official statements, the U.S. echoes the importance of a "rules-based order."

The first and most concise authoritative elucidation of the U.S. strategy for a "Free and Open Indo-Pacific" was offered by Defense Secretary Jim Mattis on June 2 at the annual Shangri-La Dialogue. Mattis outlined four main themes, largely overlapping with those of Japan, Australia, and India:

- "The maritime commons is a global good, and sea lanes of communication are the arteries of economic vitality for all." The U.S. will help "partners build up naval and law enforcement capacities to improve monitoring and protection of maritime orders and interests";

- "Interoperability. "We recognize that a network of allies and partners is a force multiplier for peace...we will ensure that our military is able to more easily integrate with others";

- "Strengthening the rule of law, civil society and transparent governance;

- "Private sector-led economic development." The U.S. will enhance "development and finance institutions, recognizing the need for greater investment, including in infrastructure" (Mattis, 2018b).

In remarks at the November 2018 APEC and East Asia Summits Vice-President Mike Pence put a sharper edge on the U.S. position, 
contrasting U.S. policies in the Indo-Pacific with those of China. Pence sought to sell the U.S. narrative, arguing that Washington seeks collaboration, not control." He proclaimed: "Know that the United States offers a better option. We don't drown our partners in a sea of debt, we don't coerce, compromise your independence," Pence said. "We do not offer constricting belt or a one-way road" (The Japan Times, 2018).

In quantitative terms, the U.S. financial commitment lags behind that of China by an order of magnitude. In his major Indo-Pacific speech last July Secretary of State Mike Pompeo offered \$113 million in development assistance as a "down payment" on a FOIP (Pompeo, 2018a). This was followed by a major reorganization of development and finance institutions last October, creating the U.S. International Development Finance Corporation, with access up to $\$ 60$ billion in funding for infrastructure projects, still modest compared to the resources mobilized by China (Thrush, 2018). The obvious effort to compete with China was undisguised.

This reflects the U.S. National Security Strategy (NSS) and Defense Strategy both released in late 2017, which place an emphasis on the security dimension of the Indo-Pacific. The NSS was the first explicit U.S. definition of China predominately as a strategic competitor: "China seeks to displace the U.S. in the Indo-Pacific region, expand the reaches of its state-driven economic model and reorder the region in its favor" (NSS, 2017, p. 25). The near-term U.S. concern is that China is seeking to dominate the first island chain around its maritime borders and pursue an anti-access strategy to limit and raise the cost to U.S. military actions in the region.

This is echoed in the Pentagon's 2018 Defense Strategy: "China is leveraging military modernization, influence operations, and predatory economics to coerce neighboring countries to reorder the Indo-Pacific region to their advantage. As China continues its economic and military ascendance... it will continue to pursue a military modernization program that seeks Indo-Pacific regional hegemony..." In response, the document touts a free and open IndoPacific and adds, "With key countries in the region, we will bring 
together bilateral and multilateral security relationships to preserve the free and open international system" (NDS, 2018).

In fact, intra-Asian security cooperation in the Indo-Pacific region has been increasing steadily over the past decade, in large measure a response to, and hedge against, a bigger Chinese footprint. U.S.Japan-Australia defense cooperation and annual trilateral meetings are a staple of U.S. Asian diplomacy. The U.S. has bolstered its defense relationship with India both bilaterally and in the annual Malabar U.S.-Japan-India military exercises (Shukla, 2017). In addition, with its \$425 million Maritime Security Initiative announced in 2015, the U.S. has been increasingly helping key ASEAN states enhance their respective maritime capabilities, particularly Vietnam, the Philippines, Malaysia, and Indonesia in response to Chinese activities in the South China Sea (Fact Sheet, 2015; see also: Parameswaran, 2016). These efforts have been loosely coordinated with Japan and Australia.

For more than a decade the region has seen a pattern of deepening intra-Asian defense cooperation-Japan, with Vietnam and the Philippines, and maritime activities among ASEAN sates, as well as, Japan-India, Indonesia-India, Singapore-Taiwan (Ratner et al, 2013). During a 2016 Summit in New Delhi, an elaborate Japan-India security and economic partnership was declared (India-Japan Joint Statement, 2017). Strengthening Japan-India collaboration is a priority for both governments. In addition, India, seeking to expand economic and defense trade with East Asia, has also been building defense cooperation with ASEAN states, particularly with Vietnam (Chaudhury, 2018). As India perceived increased maritime competition with China, in 2010, India and Vietnam upgraded their defense ties (Anand, 2017). New Delhi has become more vocal on South China Sea issues, as well as deepening its defense ties to Hanoi. On a 2016 visit to Hanoi, Indian Prime Minister Modi issued a Joint Vision Statement and New Delhi has offered $\$ 500$ million defense credits (ANI, 2016).

This regional networking-all occurring before "free and open Indo-Pacific" became the U.S. mantra-is the context in which to view the November 2017 resurrection of "the Quad"-the U.S.-Japan-IndiaAustralia-a diplomatic expression of the Indo-Pacific strategy. Contrary 
to some reports that a working level (Assistant Secretary level or lower) meeting is unlikely to become the harbinger of an "Asian NATO," it is, in effect, a modest, symbolic gesture, more like another regional talk shop and networking exercise seeking to create an agenda than a functional organization. The working level meeting was a dialogue on the range of Indo-Pacific issues discussed above (Chandran, 2018). At best, it is a work in progress that could evolve into a more functional coalition over time. Following the Quad, discussions about creating a joint regional infrastructure plan to compete with BRI ensued, but it remains at the conceptual level, and only Japan has a large-scale aid and investment program for regional infrastructure, though efforts to expand World Bank and ADB infrastructure lending are underway.

\section{INDO-PACIFIC CONTRADICTIONS}

The aspiration for a strategy to counter-balance China and bolster the rules-based order faces a host of contradictions that suggest how problematic the exercise may be. For starters, a continuing trend in the region is that economic and security issues pull in opposite directions. Economically, Asia-Pacific is an increasingly integrated region with more than fifty-three percent of its trade within the region, intraregional investment growing, and a regional economy of some \$20 trillion. Yet as outlined above, in security terms, the region is rife with distrust, territorial disputes, rising nationalisms, and irredentism, all hedging against uncertainty (see Feigenbaum and Manning, 2012). Correspondingly, something of an Asian arms race, particularly in the maritime realm, has been underway most of this century (Stavridis, 2016). While increases in military spending are slowing, Asian nations spend substantially more than Europe on defense (Béraud-Sudreau, 2017). Which of the two Asias-economic or security-will prevail?

One question arising from these discordant trends is: How will nations in the Indo-Pacific define their respective interests? That will determine the limits and possibilities of any Indo-Pacific strategy. Like China, India has historically been an autonomous strategic actor, wary of alliances, and a lingering non-aligned, anti-U.S. mindset remains in the Delhi bureaucracy. In his keynote June 1 address at the Shangri- 
La Dialogue, Prime Minister Narendra Modi emphasized that India's Indo-Pacific vision is "inclusive, and not a grouping that seeks to dominate. And by no means do we consider it directed at any country" (Modi, 2018). China is the largest trading partner of every economy in the Indo-Pacific-Japan, the ROK, ASEAN, India, and Australia.

The economic patterns render it less problematic to conceive of an inclusive economic architecture for the region than an inclusive security structure. The Comprehensive and Progressive Agreement for Trans-Pacific Partnership (CPTPP) has 11 members, and is now complete, ratified by several members and expected to enter into force at the end of December 2018 after the required majority of states have ratified it. The ROK, Thailand, Taiwan, Philippines, Indonesia, and the UK have expressed interest in joining, and of late, President Trump, who in the first week of his presidency withdrew from TPP, has on several occasions suggested interest in rejoining it, strongly encouraged by Japan. The Comprehensive and Progressive Agreement for Trans-Pacific Partnership would also be open to China at some point, though it would require major shifts in Chinese trade practices. Alternatively, the Regional Comprehensive Economic Partnership (RCEP), still being negotiated, could at some point meld with CPTPP.

In addition to the trade factor, China's Belt and Road Initiative (BRI) has an allure for the region, and Beijing has been actively cultivating projects from South Asia to ASEAN nations. Despite discomfort with China's growing regional footprint and occasional coercive tactics, few see an alternative to coming to terms with Beijing. Yet in recent months, Chinese BRI client states from Pakistan, Sri Lanka, Malaysia, Maldives, Brazil, and other nations have recoiled in protest at the neo-colonial type "debt trap" that has become associated with BRI infrastructure loans.

Yet, in what may be one of the most ill-considered aspects of U.S. Indo-Pacific policy, Pence's speeches at the APEC and the East Asia Summits, appearing to sell the U.S. approach, suggested that the U.S. wants Asians to choose between the U.S. and China, rather than seek to collaborate on infrastructure.

The biggest fear for nations in the Indo-Pacific region is having to choose between the U.S. and China. It is one thing for nations to hedge 


\section{Robert A. Manning}

with uncertainty over U.S. durability in the region and over China's emerging role. It is quite another in the event of a crisis or military conflict, in key flashpoints, for example, in the South China Sea, SinoIndia conflict, over a U.S.-China confrontation over Taiwan, or on the Korean Peninsula, to be forced to choose sides. Geography alone, with China neighboring 14 nations on the Asian mainland, and the U.S., whose territorial grasp stops at Guam and an uncertain future in the region, is compelling. Together with the large and growing economic ties between China and Asian states (for whom China is their leading trade partner) one can imagine the Asia-Pacific countries strategic calculus should hard choices be demanded.

In any case, ASEAN operates on a consensus basis, and is dedicated to a posture of neutrality, so much so that it has been politically paralyzed in the South China Sea dispute, though four of its members have disputed claims with China (Edwards, 2016). Similar dilemmas hold true for Australia, whose trade with China has been a driver of economic growth, and the ROK, whose hopes for managing the North Korea problem and reunification will require cooperation with its largest trading partner, China.

Even for the U.S., its large and complex relationship with China, $\$ 600$ billion annually in two-way trade and nearly $\$ 100$ billion invested there, need for cooperation on North Korea, Afghanistan and global issues where interests overlap, suggest that a one-dimensional labeling of Beijing a "strategic competitor" may be overly simplistic. A "free and open Indo-Pacific" may be necessary for the U.S. and its allies to sustain a rules-based order, but it is not sufficient. For example, on trade and investment issues, increasingly U.S.-EU-Japan (and other OECD economies) trilateral coordination in the WTO will increasingly be key to undoing Chinese gaming of the global economic system (see, for example: Joint Statement, 2017). In March 2018, for example, a U.S.-EUJapan trilateral complaint was filed in the WTO charging China with coerced transfer of technology as a condition for foreign investment.

Moreover, there are a host of structural issues that will limit U.S. aspirations in the Indo-Pacific. For starters, there is a resource issue: a massive U.S. domestic budget deficit, approaching \$1 trillion for 2018 
on top of a $\$ 21.21$ trillion national debt (Bartash, 2018). Then there is the on-going U.S. security commitment in the Greater Middle East, with the seventeen-year-old war in Afghanistan, indirect military involvement in Yemen and counter-terrorist focus in Syria, and no indication that the U.S. will downgrade the Middle East and shift strategic priorities to Eurasia or the Pacific. Two failed wars in Iraq and Afghanistan this century have pushed a weary U.S. public to be increasingly wary of foreign adventures-one reason for the resonance of Trump's "America First" rhetoric. All these factors-beyond the regional dynamics discussed above-suggest why the U.S. "IndoPacific strategy" may be more bark than bite.

\section{INDO-PACIFIC FUTURES}

In light of all the above-discussed factors impacting an Indo-Pacific strategy what is its likely trajectory? To conceive the spectrum of possibilities, posing alternative futures looking over the horizon to 2025 (without assigning probabilities) offers a heuristic device to better grasp the dynamics, from best to worst cases with regard to the interests of the U.S. for stability in the region:

Scenario 1: Renewed partly cooperative, partly competitive consensus. A consensus based on renovated Chinese economic reforms, opening to more FDI in restricted sectors, reducing subsidies for SOEs, reaching bilateral investment treaties with the U.S. and the EU assuring reciprocal investment; supporting WTO digital commerce and other technology agreements. In the security realm, a cooperative resolution of the North Korea nuclear problem via renewed sixparty talks, U.S.-China-ROK-DPRK talks on arms reductions and turning the armistice into a peace treaty. U.S.-China cooperation in Afghanistan, phase out of U.S. troops' presence, continued counterterrorist and counter-narcotics cooperation with frontline states (China-Russia-India-Iran-Pakistan) under SCO auspices, negotiating terms of a Taliban-dominant government in Kabul on condition of no terrorist safe havens (for a discussion of a U.S. exit from the Afghan conundrum, see: Manning, 2018). According to this scenario, the Indo-Pacific "Quad" exists as a talk shop, consultation mechanism; 
Scenario 2: Muddle through. Continued drift towards confrontation and tensions in the East and South China Seas and SinoIndian ties, limited cooperation on North Korea, interim solutionending the ICBM and nuclear program, partly dismantled, partly frozen. Continued economic jousting over trade and technology issues, with the WTO resolving some of them in U.S. favor and U.S. negotiated voluntary export restraints in sectors of Chinese overproduction. Continued efforts by the U.S. and like-minded partners to press China for more normative trade and investment behavior, pledged by Xi Jinping in his Boao Forum speech (Chu, 2018). Indo-Pacific partners deepen consultation with a focus on building capacity for security cooperation to counter-balance China, in some sort of standoff;

Scenario 3: Heightened tensions and confrontation. U.S.-China trade confrontation escalates, both sides believing they can prevail. This is but one aspect of a Sino-U.S. Cold War confrontation. Trade dispute hits stock markets and slows growth in the region. After a protracted period, modest steps to partially resolve trade conflict. Geopolitical tensions grow-Sino-Indian over disputed borders in Himalayas, India's maritime fears of encirclement with China building ports in Gwadar, Sri Lanka, Maldives, Bangladesh; U.S.-Chinese over Taiwan, and over increased U.S. and Chinese military activities in the South China Sea. On North Korea, China presses both Koreas for a nuclear freeze, U.S. opposes.

The latter scenario is a harbinger of a new Cold War-like divide. Miscalculation could trigger conflict with the potential to escalate in each of these situations. The Quad becomes a more active strategic planning forum aimed at countering Chinese anti-access policies and pressing other Asian actors to tilt against China, with very limited success. This scenario is a harbinger of a fragmenting world order along regional sphere-of-influence lines. Region-centric trade leads the way with Europe, North America, Latin American, and pan-Asian trade configurations. 


\section{References}

Abe, S., 2007. Confluence of the two seas. Speech by H.E. Shinzo Abe, Prime Minister of Japan at the Parliament of the Republic of India [online]. Available at: <https://www.mofa.go.jp/region/asia-paci/pmv0708/speech-2.html> [Accessed 25 November 2018].

Anand, B.V., 2017. Achievements: India-Vietnam defence and security cooperation. Vivekananda International Foundation, 12 May 12 [online]. Available at: <https://www.vifindia.org/article/2017/may/12/achievementsindia-vietnam-defence-and-security-cooperation $>$ [Accessed 25 November 2018].

ANI, 2016. PM Modi's visit to Vietnam kicks off with defence, trade as top agendas. The Indian Express, 02 September [online]. Available at: <https://indianexpress. com/article/india/india-news-india/pm-narendra-modi-visit-vietnam-nguyenxuan-phuc-tran-dai-quang-india-kicks-off-two-nation-tour-with-with-defencetrade-as-top-agenda-3010193/> [Accessed 25 November 2018].

Asia Security Initiative, 2018. A Free and Open Indo-Pacific Strategy. Atlantic Council. [online]. Available at: <https://www.atlanticcouncil.org/events/pastevents/a-free-and-open-indo-pacific-strategy> [Accessed 24 November 2018].

Barris, M., 2014. Replace dollar with super currency: economist. China Daily USA, 29 January [online]. Available at: <http://usa.chinadaily.com.cn/ world/2014-01/29/content_17264069.htm> [Accessed 24 November 2018].

Bartash, J., 2018. Here's who owns a record \$21.21 trillion of U.S. debt. MarketWatch [online]. Available at: <https://www.marketwatch.com/story/ heres-who-owns-a-record-2121-trillion-of-us-debt-2018-08-21> [Accessed 26 November 2018].

Béraud-Sudreau, L., 2017. Defence-spending trends in Asia: a slowing pace? IISS, 02 June [online]. Available at: <https://www.iiss.org/blogs/analysis/2017/06/ defence-spending-asia> [Accessed 26 November 2018].

Blanchard, B., and Gao, L., 2018. China building on new reef in South China Sea, think tank says. Reuters, 21 November [online]. Available at: <https:// www.reuters.com/article/us-china-southchinasea/china-building-on-newreef-in-south-china-sea-think-tank-says-idUSKCN1NQ08Y> [Accessed 26 November 2018].

Brown, J.D.J., 2018. Japan's Values-Free and Token Indo-Pacific Strategy. The Diplomat, 30 March [online]. Available at: <https://thediplomat.com/2018/03/ 


\section{Robert A. Manning}

japans-values-free-and-token-indo-pacific-strategy/> [Accessed 25 November 2018].

Campbell, K.M., and Ratner, E., 2018. The China reckoning. Foreign Affairs, 97(2), 5 December [online]. Available at: <https://www.foreignaffairs.com/ articles/united-states/2018-02-13/china-reckoning > [Accessed 24 November 2018].

Chandran, N., 2018. The US and its Asia Pacific allies are boosting security ties - that could upset China. CNBC, 22 March [online]. Available at: <https:// www.cnbc.com/2018/03/22/us-japan-india-and-australia-security-talkscould-anger-china.html $>$ [Accessed 25 November 2018].

Chaudhury, D.R., 2018. India, ASEAN leaders agree to boost maritime cooperation. The Economic Times, 26 January [online]. Available at: <https:// economictimes.indiatimes.com/news/defence/india-asean-leaders-agree-toboost-maritime-cooperation/articleshow/62654982.cms> [Accessed 25 November 2018].

Chu, K., 2018. Ball in Donald Trump's court as Xi Jinping champions free trade at Boao Forum. South China Morning Post, 14 April [online]. Available at: <https://www.scmp.com/news/china/article/2141754/ball-donald-trumpscourt-xi-jinping-champions-free-trade-boao-forum $>$ [Accessed 27 November 2018].

Clinton, H., 2011. America's Pacific Century. Foreign Policy, 11 October [online]. Available at: $<$ http://foreignpolicy.com/2011/10/11/americas-pacificcentury/> [Accessed 24 November 2018].

EAF Editorial Board, 2018. China-Japan cooperation going global. EastAsiaForum, 29 October [online]. Available at: <http://www.eastasiaforum. org/2018/10/29/china-japan-cooperation-going-global/> [Accessed 26 November 2018].

East Asian Strategy Report, 1998. The United States Security Strategy for the East Asia-Pacific Region [pdf]. Available at: <http://ryukyu-okinawa.net/ downloads/usdod-easr98.pdf $>$ [Accessed 24 November 2018].

Economist, 2018. China's tech industry is catching up with Silicon Valley. Economist, 16 February [online]. Available at: <https://www.economist.com/ graphic-detail/2018/02/16/chinas-tech-industry-is-catching-up-with-siliconvalley> [Accessed 24 November 2018]. 
Edwards, S., 2016. Why ASEAN must remain neutral on the South China Sea. The Diplomat, 31 March [online]. Available at: <https://thediplomat. com/2016/03/why-asean-must-remain-neutral-on-the-south-china-sea/> [Accessed 26 November 2018].

Fact Sheet, 2015. FACT SHEET: U.S. Building maritime capacity in Southeast Asia. The White House. Office of the Press Secretary, 17 November [online]. Available at: <https://obamawhitehouse.archives.gov/the-pressoffice/2015/11/17/fact-sheet-us-building-maritime-capacity-southeast-asia $>$ [Accessed 25 November 2018].

Feigenbaum, E.A., and Manning, R.A., 2012. A tale of two Asias. Foreign Policy, 31 October [online]. Available at: <https://foreignpolicy.com/2012/10/31/atale-of-two-asias/> [Accessed 26 November 2018].

Goswami, N., 2017. Can China be taken seriously on its 'word' to negotiate disputed territory? The Diplomat, 18 August [online]. Available at: <http:// thediplomat.com/2017/08/can-china-be-taken-seriously-on-its-word-tonegotiate-disputed-territory/> [Accessed 24 November 2018].

India-Japan Joint Statement, 2017. India-Japan Joint Statement during visit of Prime Minister of Japan to India (September 14, 2017) [online]. Available at: $<$ https://www.mea.gov.in/bilateral-documents.htm?dtl/28946/IndiaJapan+Joi $\mathrm{nt}+$ Statement+during+visit+of+Prime+Minister+of+Japan+to+India+Septem ber+14+2017> [Accessed 25 November 2018].

Johnson, J., 2017. Japan's fighter jet scrambles set new record in 2016 amid surging Chinese military activity. Japan Times, 14 April [online]. Available at: $<$ https://www.japantimes.co.jp/news/2017/04/14/national/japans-fighter-jetscrambles-set-new-record-2016-amid-surging-chinese-military-activity/\#. WZ3LM2epV9A $>$ [Accessed 24 November 2018].

Joint Statement, 2017. Joint Statement by the United States, European Union and Japan at MC11. Office of the United States Trade Representative, 12 December, [online]. Available at: <https://ustr.gov/about-us/policy-offices/press-office/ press-releases/2017/december/joint-statement-united-states $>$ [Accessed 26 November 2018].

Lee, A., 2017. World dominance in three steps: China sets out road map to lead in artificial intelligence by 2030. South China Morning Post, 21 July [online]. Available at: <https://www.scmp.com/tech/enterprises/article/2103568/worlddominance-three-steps-china-sets-out-road-map-lead-artificial> [Accessed 24 November 2018]. 


\section{Robert A. Manning}

Manning, R.A., 2018. The United States needs an Afghanistan exit strategy. Foreign Policy, 05 October [online]. Available at: <https://foreignpolicy. com/2018/10/05/the-end-game-in-afghanistan-china-pakistan-nato-unitedstates/> [Accessed 26 November 2018].

Masuda, M., 2016. Why has Chinese foreign policy become more assertive? EastAsiaForum, 20 February [online]. Available at: $<\mathrm{http} / /$ www.eastasiaforum. org/2016/02/20/why-has-chinese-foreign-policy-become-more-assertive/> [Accessed 24 November 2018].

Mattis, J., 2018a. Press availability with Secretary of Defense James Mattis, Chinese Politburo Member Yang Jiechi, and Chinese State Councilor and Defense Minister General Wei Fenghe. 5 November [online]. Available at: $<$ https://www.state.gov/secretary/remarks/2018/11/287279.htm> [Accessed 24 November 2018].

Mattis, J., 2018b. Remarks by Secretary Mattis at Plenary Session of the 2018 Shangri-La Dialogue. 2 June [online]. Available at: <https://dod.defense.gov/ News/Transcripts/Transcript-View/Article/1538599/remarks-by-secretarymattis-at-plenary-session-of-the-2018-shangri-la-dialogue/> [Accessed 25 November 2018].

Modi, N., 2018. Prime Minister's Keynote Address at Shangri La Dialogue (June 01, 2018). Ministry of Foreign Affairs, Government of India [online]. Available at: $<$ https://www.mea.gov.in/Speeches-Statements.htm?dtl/29943/Prime+Minist ers + Keynote + Address + at + Shangri + La + Dialogue + June $+01+2018>$ [Accessed 26 November 2018].

NDS, 2018. Summary of the National Defense Strategy of the United States of America [online]. Available at: $<$ https://dod.defense.gov/Portals/1/Documents/ pubs/2018-National-Defense-Strategy-Summary.pdf $>$ [Accessed 25 November 2018].

NSS, 2017. National Security Strategy of the United States of America. December [online]. Available at: <https://www.whitehouse.gov/wp-content/ uploads/2017/12/NSS-Final-12-18-2017-0905.pdf> [Accessed 24 November 2018].

Parameswaran, P., 2016. The US kicks off ew Maritime Security Initiative for Southeast Asia. The Diplomat, 10 April [online]. Available at: <https:// thediplomat.com/2016/04/us-kicks-off-new-maritime-security-initiative-forsoutheast-asia/> [Accessed 25 November 2018]. 
Paulson, H.M., 2018. Remarks by Henry M. Paulson, Jr., on the United States and China at a crossroads. Address to the Bloomberg New Economy Forum. Paulson Institute, 6 November [online]. Available at: <http://www.paulsoninstitute.org/ news/2018/11/06/statement-by-henry-m-paulson-jr-on-the-united-statesand-china-at-a-crossroads/> [Accessed 16 December 2018].

Pompeo, M., 2018a. Remarks on "America's Indo-Pacific Economic Vision". Indo-Pacific Business Forum. U.S. Chamber of Commerce [online]. Available at: $<$ https://www.state.gov/secretary/remarks/2018/07/284722.htm $>$ [Accessed 24 November 2018].

Pompeo, M., 2018b. Press availability with Secretary of Defense James Mattis, Chinese Politburo Member Yang Jiechi, and Chinese State Councilor and Defense Minister General Wei Fenghe. 5 November [online]. Available at: $<$ https://www.state.gov/secretary/remarks/2018/11/287279.htm> [Accessed 24 November 2018].

Ratner, E. et al, 2013. The emerging Asia power web: the rise of bilateral intraAsian security ties. Center for a New American Security, 10 June [online]. Available at: <https://www.cnas.org/publications/reports/the-emergingasia-power-web-the-rise-of-bilateral-intra-asian-security-ties> [Accessed 25 November 2018].

Santos, M., 2016. Philippines wins arbitration case vs. China over South China Sea. Global Nation Inquirer, 12 July [online]. Available at: <http://globalnation. inquirer.net/140358/philippines-arbitration-decision-maritime-disputesouth-china-sea-arbitral-tribunal-unclos-itlos $>$ [Accessed 24 November 2018].

Shukla, T., 2017. India, Japan to step up defence ties, deepen Malabar exercise with US. Livemint 06 September [online]. Available at: <https://www. livemint.com/Politics/7RJdW3Yxt93lqcSMpJhuIM/India-Japan-to-stepup-defence-ties-deepen-Malabar-exercis.html?utm_source=scroll\&utm medium $=$ referral\&utm_campaign=scroll $>$ [Accessed 25 November 2018].

Stavridis, J., 2016. James Stavridis:" Submarines are a new facet of Asia's arms race." Nikkei Asian Review, 26 May [online]. Available at: <https://asia.nikkei. com/Politics/James-Stavridis-Submarines-are-a-new-facet-of-Asia-s-armsrace> [Accessed 26 November 2018].

Swaine, M. D., 2010. China's Assertive Behavior. Part One. China Leadership Monitor, no. 34 [pdf] Available at: <http://carnegieendowment.org/files/ CLM34MS_FINAL.pdf> [Accessed 24 November 2018]. 
The Japan Times, 2018. China, U.S. trade fiery barbs in speeches at Pacific summit. The Japan Times, 17 November [online]. Available at: <https://www. japantimes.co.jp/news/2018/11/17/asia-pacific/politics-diplomacy-asiapacific/china-u-s-trade-barbs-speeches-pacific-summit/\#.XAfuNmgzaUl> [Accessed 26 November 2018].

Thrush, G., 2018. Trump embraces foreign aid to Ccounter China's global influence. The New York Times, 14 October [online]. Available at: <https:// www.nytimes.com/2018/10/14/world/asia/donald-trump-foreign-aid-bill. html $>$ [Accessed 24 November 2018].

White Paper, 2017. Foreign Policy White Paper. Australian Government [online]. Available at: $<$ https://www.fpwhitepaper.gov.au/foreign-policy-whitepaper> [Accessed 25 November 2018].

Wübbeke, J., et al, 2017. Made in China 2015. Merics. Papers on China [pdf]. Available at: <https://www.merics.org/sites/default/files/2017-09/MPOC_ No.2_MadeinChina2025.pdf> [Accessed 24 November 2018].

$\mathrm{Xi}$, J., 2017. Secure a decisive victory in building a moderately prosperous society in all respects and strive for the great success of socialism with Chinese characteristics for a new era. Address at the 19th National Congress of the Communist Party of China, October 18 [online]. Available at: <http:// www.xinhuanet.com/english/download/Xi_Jinping's_report_at_19th_CPC_ National_Congress.pdf $>$ [Accessed 24 November 2018].

Xinhua Net, 2016. China has indisputable sovereignty over South China Sea islands. Xinhua, 29 April [online]. Available at: <http://news.xinhuanet.com/ english/2016-04/29/c_135322815.htm> [Accessed 24 November 2018]. 